\title{
Pulmonary to Systemic Flow Ratio in Precapillary Pulmonary Hypertension Without Left-to-Right Shunts: A Prognostic Implication of the Fick Method
}

\author{
Soldan Sağa Şantı Olmayan Prekapiller Pulmoner Hipertansiyonda Pulmoner/ \\ Sistemik Akım Oranı: Fick Yönteminin Prognostik Bir Sonucu
}

\author{
(D) Bihter Şentürk1 , (1) Bahri Akdeniz¹, (1) Mehmet Birhan Yılmaz¹, (1) Ebru Özpelit1', (D) Dilek Sezgin² \\ (D) Buse Özcan Kahraman³, (D) Burak Acar ${ }^{4}$, (D) Kemal Can Tertemiz ${ }^{5}$, (D) Merih Birlik ${ }^{6}$, (D) Can Sevinç \\ ${ }^{1}$ Dokuz Eylül University Faculty of Medicine, Department of Cardiology, İzmir, Turkey \\ ${ }^{2}$ Dokuz Eylül University Faculty of Nursing, Department of Internal Medicine Nursing, İzmir, Turkey \\ ${ }^{3}$ Dokuz Eylül University, School of Physical Therapy and Rehabilitation, İzmir, Turkey \\ ${ }^{4}$ Kocaeli University Faculty of Medicine, Department of Cardiology, Kocaeli, Turkey \\ ${ }^{5}$ Dokuz Eylül University Faculty of Medicine, Department of Chest Disease, İzmir, Turkey \\ ${ }^{6}$ Dokuz Eylül University Faculty of Medicine, Department of Internal Medicine, Division of Immunology and Rheumatology, İzmir, Turkey
}

\begin{abstract}
Objective: We routinely calculate the pulmonary to systemic (Qp/Qs) ratio to avoid missing any left-to-right shunts in patients with precapillary pulmonary hypertension $(\mathrm{PH})$. However, the pulmonary artery oxygen saturation $\left(\mathrm{SpaO}_{2}\right)$ was lower than the mixed venous oxygen saturation $\left(\mathrm{SmvO}_{2}\right)$ calculated using the formula; hence, the $\mathrm{Qp} / \mathrm{Qs}$ ratio was calculated as less than "1" in some patients despite the absence of any detectable shunt. We hypothesized that this observation might have prognostic significance; however, to the best of our knowledge, it has not been investigated yet. Therefore, we aimed to examine the prognostic value of the Qp/Qs ratio in precapillary PH without left-to-right shunts.

Methods: In this retrospective cohort study of 173 consecutive patients, hospital files were scanned for clinical, echocardiographic, and hemodynamic data including the Qp/Qs ratio calculated using the Fick method.

Results: During a median follow-up of 25 months, 74 patients died. Nonsurvivors had lower $Q p / Q s$ ratio than survivors $(0.76 \pm 0.19$ vs. $1.02 \pm 0.07$ $\mathrm{p}<0.001$ ). The multivariate logistic regression analysis showed that a decreased $\mathrm{Qp} / \mathrm{Qs}$ ratio and poor functional capacity (World Health Organization class III-IV) were independent predictors of mortality. The receiver operating characteristic curve analysis revealed that the optimal cutoff value of the $\mathrm{Qp} / \mathrm{Qs}$ ratio for predicting mortality was 0.90 with a sensitivity of $76 \%$ and specificity of $98 \%$.

Conclusion: The $\mathrm{Qp} / \mathrm{Qs}$ ratio calculated using the Fick method was an independent predictor of mortality. This prognostic implication was based on the difference between $\mathrm{SpaO}_{2}$ and $\mathrm{SmvO}_{2}$ calculated using the formula. Nevertheless, this result might be a reflection of a potential intrinsic methodological flaw of the Fick method.
\end{abstract}

Keywords: Pulmonary hypertension, prognosis, fick method, oxygen, mortality

\section{öz}

Amaç: Prekapiller pulmoner hipertansiyonlu (PH) hastalarda soldan sağa şantları kaçırmamak için pulmoner/sistemik oranı (Qp/Qs) rutin olarak hesaplamaktayız. Şaşırtıı bir şekilde pulmoner arter oksijen satürasyonunun $\left(\mathrm{SpaO}_{2}\right)$ formülle hesaplanan mikst venöz oksijen satürasyonundan $\left(\mathrm{SmvO}_{2}\right)$ daha düşük olduğunu gözlemledik. Bu nedenle, saptanabilir herhangi bir şant olmamasına rağmen bazı hastalarda Qp/Qs değeri "1"den küçük olarak hesaplandı. Bu gözlemin prognostik öneme sahip olabileceğini varsaydık ve bildiğimiz kadarıyla bu henüz çalışılmadı. Bu nedenle soldan sağa şantı olmayan prekapiller PH'de Qp/Qs'in prognostik değerini araştırmayı amaçladık.

Gereç ve Yöntem: Ardışık 173 hastayı içeren bu retrospektif kohort çalışmada, hastane dosyaları, Fick yöntemiyle hesaplanan Qp/Qs'i de içeren klinik, ekokardiyografik ve hemodinamik veriler için tarandı.

Address for Correspondence: Bihter Şentürk, Dokuz Eylül University Faculty of Medicine, Department of Cardiology, İzmir,

Turkey

Phone: +90 5325164926 E-mail: drbihter@hotmail.com ORCID ID: orcid.org/0000-0003-3568-4476

Cite as: Şentürk B, Akdeniz B, Yılmaz MB, Özpelit E, Sezgin D, Özcan Kahraman B, Acar B, Tertemiz KC, Birlik M, Sevinç Can. Pulmonary to Systemic Flow Ratio in Precapillary Pulmonary Hypertension Without Left-to-Right Shunts: A Prognostic Implication of the Fick Method. 
Bulgular: Ortanca 25 ay takipte 74 hasta öldü. Ölenler, hayatta kalanlardan daha düşük Op/Qs'e sahiplerdi $(0,76 \pm 0,19$ 'a karşılık 1,02 $\pm 0,07$; $p<0,001)$. Çok değişkenli lojistik regresyon analizi, düşük Qp/Qs ve kötü fonksiyonel kapasitesinin (Dünya Sağlık Örgütü sınıf III-IV) mortalitenin bağımsız öngörücüleri olduğunu gösterdi. ROC eğrisi analizi, mortaliteyi tahmin etmek için Qp/Qs'in optimal kestirim değerinin \%76 duyarlılık ve \%98 özgüllük ile 0,90 olduğunu ortaya koydu.

Sonuç: Fick yöntemiyle hesaplanan $\mathrm{Qp} / \mathrm{Qs}^{\prime}$ in mortalitenin bağımsız bir öngördürücüsü olduğu gösterildi. Bu prognostik çıkarım, SpaO ${ }_{2}$ ile formül aracılığıyla hesaplanan $\mathrm{SmvO}_{2}$ arasındaki farka dayanmaktadır. Bununla birlikte, bu sonuç, Fick yönteminin potansiyel bir içsel metodolojik kusurunun bir yansıması olabilir.

Anahtar Kelimeler: Pulmoner hipertansiyon, prognoz, fick yöntemi, oksijen, mortalite

\section{INTRODUCTION}

Pulmonary hypertension $(\mathrm{PH})$ is characterized by elevated mean pulmonary artery pressure (mPAP) of $\geq 25 \mathrm{mmHg}$ at rest during right-sided cardiac catheterization (RSCC) (1). $\mathrm{PH}$ is a life-threatening condition that ultimately causes right ventricular failure and death. Since the prognostic evaluation is critical for $\mathrm{PH}$, several risk assessment tools were developed to predict its prognosis and optimize treatment (2-7).

RSCC is accepted as the gold standard diagnostic tool for the definitive diagnosis of $\mathrm{PH}$ and used for prognostic purposes (1). The pulmonary to systemic flow ( $\mathrm{Qp} / \mathrm{Qs}$ ) ratio is a calculation for estimating the direction and severity of shunting, especially in congenital heart diseases. This ratio is typically calculated using the Fick method (8), and it is essential in the differential diagnosis and management of $\mathrm{PH}$ in patients with left-to-right shunts (9). We routinely calculate the $\mathrm{Qp} / \mathrm{Qs}$ ratio to avoid missing any left-toright shunts in patients with precapillary $\mathrm{PH}$. However, the pulmonary artery oxygen saturation $\left(\mathrm{SpaO}_{2}\right)$ was lower than the mixed venous oxygen saturation $\left(\mathrm{SmvO}_{2}\right)$ calculated using the formula; hence, the $\mathrm{Qp} / \mathrm{Q}$ s ratio was calculated as less than " 1 " in some patients despite the absence of any detectable shunt. We hypothesized that this observation might have prognostic significance; however, to the best of our knowledge, it has not been investigated yet. Therefore, we aimed to investigate the prognostic value of the $\mathrm{Qp} /$ Qs ratio in patients with precapillary $\mathrm{PH}$ without any left-toright shunt.

\section{METHODS}

\section{Study Population}

This retrospective cohort study was conducted in the Department of Cardiology of Dokuz Eylül University Hospital. This study was approved by the Local Ethics Committee. Informed consent was obtained for the RSCC procedure from all patients.

The medical records of 225 consecutive patients who underwent RSCC combined with oximetric study through the Fick method (8) for differential diagnosis of PH were screened from the hospital database. All patients were diagnosed with precapillary PH by an algorithm recommended in the guideline (1). After excluding 52 patients with confirmed left-to-right shunt not only through the oximetric analysis but also with other diagnostic modalities, the remaining 173 patients with precapillary PH were considered for the final analysis. Precapillary PH was defined as mPAP $\geq 25 \mathrm{mmHg}$ along with pulmonary artery wedge pressure (PAWP) $\leq 15$ $\mathrm{mmHg}$ (1).

\section{Transthoracic Doppler Echocardiography}

Thorough transthoracic echocardiography that specifically focused on investigating the function and pressure within the right side of the heart was performed by using a Philips HD11 XE Ultrasound system with 3.2 MHz transducer (Philips Healthcare, Best, Netherlands).

\section{Data Collection and Patient Follow-up}

All patients were routinely evaluated every 3 months in the $\mathrm{PH}$ outpatient clinic. The functional capacity (FC) of the patients was recorded according to the World Health Organization (WHO) functional classification (10). Results of the 6-min walking distance (6MWD) test, echocardiographic values, and laboratory parameters were obtained. All-cause mortality was noted during follow-up, and patients were compared as survivors versus nonsurvivors for analysis.

\section{Right-Sided Cardiac Catheterization}

All patients underwent RSCC at rest that was performed by experienced cardiologists. Neither sedation nor supplemental oxygen was administered during the study. Pressure records and the oximetric study were performed with multipurpose angled catheters (end hole only). The right atrial pressure and PAP, along with the PAWP, were recorded. Blood samples from the pulmonary artery, right atrium, right ventricle, superior vena cava (SVC), inferior vena cava (IVC), and systemic artery were obtained routinely, and the $Q p / Q s$ ratio was calculated using the following formula: systemic artery oxygen saturation - $\mathrm{SmvO}_{2} /$ pulmonary artery wedge oxygen saturation $-\mathrm{SpaO}_{2}$ (8). To calculate $\mathrm{SmvO}_{2}$, this formula was used: [( $3 \times \mathrm{SVC}$ oxygen saturation $\left(\mathrm{SsvcO}_{2}\right)+$ IVC oxygen saturation $\left.\left.\left(\mathrm{SivcO}_{2}\right)\right) / 4\right]$ (11). In cases with no record of the pulmonary artery wedge saturation, 
it was assumed to be similar to the systemic artery oxygen saturation. The cardiac index was calculated by dividing Qs values by the measure of the total surface area of the body. Transpulmonary gradient determined by subtracting PAWP from mPAP was divided by $\mathrm{Qp}$ to calculate the pulmonary vascular resistance (PVR).

\section{Statistical Analysis}

Statistical analyses were performed using SPSS 25.0 (institutionally registered software). Normality was assessed with the Kolmogorov-Smirnov test. Data were reported as percentages for categorical variables and mean \pm standard deviation or median (interquartile range) for continuous variables. Student's t-test or Mann-Whitney $U$ test was used to compare continuous variables, and the appropriate chi-squared test was performed to compare categorical variables. To predict mortality, the optimal cutoff threshold for the Qp/Qs ratio was obtained by analyzing the receiver operating characteristics (ROC) curve. The Kaplan-Meier analysis with a cutoff value of 0.90 for the $\mathrm{Qp} / \mathrm{Qs}$ ratio was used to designate the survival curves. Logistic regression analyses were performed to define predictors of mortality. Variables with $p$-value $<0.1$ in the univariate regression analysis were included in the multivariate logistic regression analysis. For all statistical analyses, $p$-value of $\leq 0.05$ was accepted as significant.

\section{RESULTS}

This study included 45 men and 128 women, with a mean age of $60.2 \pm 15.5$ years. The follow-up duration ranged from 25 months to 128 months. A total of 74 (42.7\%) deaths were noted during the follow-up. Baseline demographics and clinical and echocardiographic comparisons of survivors versus nonsurvivors are presented in Table 1. According to functional class, $91.8 \%$ of the nonsurvivors and $54.5 \%$ of the survivors had WHO FC III-IV. Nonsurvivors had significantly lower 6MWD, tricuspid annular plane systolic excursion, and right ventricular outflow tract maximum systolic velocity values. Pericardial effusion more frequently occurred in nonsurvivors, and they had significantly higher brain natriuretic peptide and lactate dehydrogenase levels (Table 1).

Baseline hemodynamic data obtained from RSCC are shown in Table 2. Nonsurvivors had significantly lower $Q p$ and $Q p /$ Qs ratio (3.52 \pm 1.48 vs. $4.53 \pm 1.43, p<0.001 ; 0.76 \pm 0.19$ vs. $1.02 \pm 0.07, p<0.001)$ than survivors, respectively. The mPAP and PVR levels were significantly higher in nonsurvivors.

The multivariate logistic regression analysis showed that the Qp/Qs ratio and poor FC (WHO FC III-IV) ( $p=0.002$,
Table 1. Baseline clinical and echocardiographic characteristics of the study population

\begin{tabular}{|c|c|c|c|}
\hline Variables & $\begin{array}{l}\text { Survivors } \\
(n=99)\end{array}$ & $\begin{array}{l}\text { Non-survivors } \\
(n=74)\end{array}$ & $p$ \\
\hline Female n (\%) & $72(72.7)$ & $56(75.7)$ & 0.662 \\
\hline Age (year) & $58.97 \pm 15.3$ & $61.0 \pm 16.3$ & 0.384 \\
\hline $\begin{array}{l}\text { WHO/FC III-IV } \\
\text { n (\%) }\end{array}$ & $48(54.5)$ & $67(91.8)$ & $<0.001$ \\
\hline $\begin{array}{l}\text { 6-min walking } \\
\text { distance }(m)\end{array}$ & $330(221-380)$ & $264(120-320)$ & 0.043 \\
\hline $\mathrm{BNP}(\mathrm{pg} / \mathrm{mL})$ & $206(100-442)$ & $614(253-1186)$ & $<0.001$ \\
\hline $\begin{array}{l}\text { Hemoglobin (mg/ } \\
\mathrm{dL} \text { ) }\end{array}$ & $12.43 \pm 2.23$ & $12.29 \pm 2.32$ & 0.714 \\
\hline Uric acid (mg/dL) & $6.89 \pm 2.44$ & $7.02 \pm 2.38$ & 0.751 \\
\hline $\begin{array}{l}\text { Serum LDH (mg/ } \\
\mathrm{dL})\end{array}$ & $223(183-263)$ & 265 (188-344) & 0.027 \\
\hline sPAP $(\mathrm{mmHg})$ & $79.38 \pm 20.19$ & $82.76 \pm 16.92$ & 0.255 \\
\hline TAPSE $(\mathrm{mm})$ & $18.1 \pm 5.3$ & $16.1 \pm 4.8$ & 0.020 \\
\hline $\begin{array}{l}\text { RVOT maximum } \\
\text { systolic velocity } \\
(\mathrm{m} / \mathrm{sec})\end{array}$ & $0.87 \pm 0.20$ & $0.75 \pm 0.18$ & 0.002 \\
\hline $\begin{array}{l}\text { Pericardial } \\
\text { effusion, n (\%) }\end{array}$ & $14(15.7)$ & $27(43.5)$ & $<0.001$ \\
\hline \multicolumn{4}{|c|}{$\begin{array}{l}\text { WHO/FC: World Health Organization/functional capacity, BNP: Brain } \\
\text { natriuretic peptide, LDH: Lactate dehydrogenase, sPAP: Systolic pulmonary } \\
\text { arterial pressure, TAPSE: Tricuspid annular plane systolic excursion, RVOT: } \\
\text { Right ventricular outflow tract }\end{array}$} \\
\hline
\end{tabular}

Table 2. Baseline hemodynamic data obtained from right-sided cardiac catheterization

\begin{tabular}{|c|c|c|c|}
\hline Variables & $\begin{array}{l}\text { Survivors } \\
(\mathrm{n}=99)\end{array}$ & $\begin{array}{l}\text { Non- } \\
\text { survivors } \\
(n=74)\end{array}$ & $p$ \\
\hline Qp (L/min) & $4.53 \pm 1.43$ & $3.52 \pm 1.48$ & $<0.001$ \\
\hline Qs (L/min) & $4.5 \pm 1.5$ & $4.7 \pm 1.7$ & 0.431 \\
\hline Qp/Os ratio & $1.02 \pm 0.07$ & $0.76 \pm 0.19$ & $<0.001$ \\
\hline $\begin{array}{l}\text { Systolic PAP at } \\
\text { catheterization }(\mathrm{mmHg})\end{array}$ & $73.4 \pm 23.3$ & $77.7 \pm 18.0$ & 0.207 \\
\hline $\begin{array}{l}\text { Mean PAP at } \\
\text { catheterization }(\mathrm{mmHg})\end{array}$ & $43.0 \pm 12.5$ & $47.1 \pm 12.1$ & 0.038 \\
\hline $\begin{array}{l}\text { Diastolic PAP at } \\
\text { catheterization }(\mathrm{mmHg})\end{array}$ & $25.57 \pm 10.10$ & $28.23 \pm 9.42$ & 0.093 \\
\hline $\begin{array}{l}\text { Pulmonary vascular } \\
\text { resistance (wood unit) }\end{array}$ & $6.5(4.1-9.5)$ & $8.6(5.0-12.8)$ & 0.006 \\
\hline $\begin{array}{l}\text { Right atrial pressure } \\
(\mathrm{mmHg})\end{array}$ & $10.7 \pm 5.3$ & $10.2 \pm 6.0$ & 0.598 \\
\hline $\begin{array}{l}\text { Cardiac index }(\mathrm{L} / \mathrm{min} / \\
\left.\mathrm{m}^{2}\right)\end{array}$ & $2.5 \pm 0.8$ & $2.7 \pm 0.9$ & 0.147 \\
\hline
\end{tabular}

Qp: Pulmonary blood flow, Qs: Systemic blood flow, Qp/Qs: pulmonary to systemic blood flow ratio, PAP: Pulmonary arterial pressure 
$p<0.001$ respectively) were independent predictors of mortality (Table 3). The optimal Qp/Os cutoff for predicting mortality was 0.90 with $76 \%$ sensitivity and $98 \%$ specificity (area under the curve $=0.845,95 \% \mathrm{Cl}: 0.778-0.913, \mathrm{p}<0.001$ ) based on the ROC curve analysis (Figure 1). The KaplanMeier analysis of $\mathrm{Qp} / \mathrm{Qs}>0.90$ and $\mathrm{Qp} / \mathrm{Q} s \leq 0.90$ yielded diverging survival curves $(p<0.001)$ (Figure 2$)$. $Q p / Q s \leq 0.90$ was noted in $34.7 \%$ of the patients, and $\mathrm{Qp} / \mathrm{Qs}$ ratio $\leq 0.90$ was significantly more common in nonsurvivors than in survivors $(75.7 \%$ vs. $4 \% ; p<0.001)$.

\section{DISCUSSION}

Hemodynamic parameters obtained from RSCC are valuable for predicting the prognosis of $\mathrm{PH}$ (1). The Fick method relies on measuring oxygen concentrations in blood samples obtained by a catheter positioned at several points and serves as a reference procedure for the evaluation of blood flow (Qp/Qs) (8) and shunts (9). Op, Qs, and $Q p / Q s$ ratio are routinely calculated in patients

Table 3. Multivariate logistic regression analysis to predict mortality

\begin{tabular}{lllll}
\hline Variables & Univariate OR, 95\% Cl & $p$ & Multivariate OR, 95\% Cl & $p$ \\
\hline WHO/FC III-IV & $6.306(3.654-8.696)$ & $<0.001$ & $7.297(2.410-9.257)$ & $<0.001$ \\
\hline 6MWD & $0.997(0.995-1.0)$ & 0.046 & $0.993(0.984-1.002)$ & 0.149 \\
\hline BNP & $1.001(1.000-1.001)$ & 0.001 & $0.999(0.998-1.001)$ & 0.561 \\
\hline Serum LDH & $1.005(1.001-1.008)$ & 0.010 & $1.009(0.996-1.022)$ & 0.164 \\
\hline TAPSE & $0.925(0.865-0.989)$ & 0.023 & $1.124(0.851-1.486)$ & 0.410 \\
\hline RVOT maximum systolic velocity & $0.162(0.023-1.165)$ & 0.071 & $0.205(0.027-0.826)$ & 0.504 \\
\hline Pericardial effusion, & $0.443(0.267-0.737)$ & $<0.001$ & $0.729(0.371-1.432)$ & 0.246 \\
\hline Qp/Qs & $0.599(0.467-0.770)$ & $<0.001$ & $0.117(0.030-0.450)$ & 0.002 \\
\hline Mean PAP at catheterization & $1.027(1.027-1.054)$ & 0.040 & $0.995(0.893-1.108)$ & 0.206 \\
\hline Variabs
\end{tabular}

Variables entered into the univariate logistic regression analysis: sex, age, WHO/FC III-IV, 6MWD, BNP, hemogram, uric acid, serum LDH, systolic pulmonary arterial pressure, TAPSE, RVOT maximum systolic velocity, pericardial effusion, Qp/Qs ratio, systolic PAP at catheterization (mmHg), mean PAP at catheterization $(\mathrm{mmHg})$, pulmonary vascular resistance, right atrial pressure, cardiac index. WHO/FC: World Health Organization/functional capacity, 6MWD: 6-min walking distance, BNP: Brain natriuretic peptide, LDH: Lactate dehydrogenase, TAPSE: Tricuspid annular plane systolic excursion, RVOT: Right ventricular outflow tract, Qp/Os: pulmonary to systemic blood flow ratio, PAP: Pulmonary arterial pressure

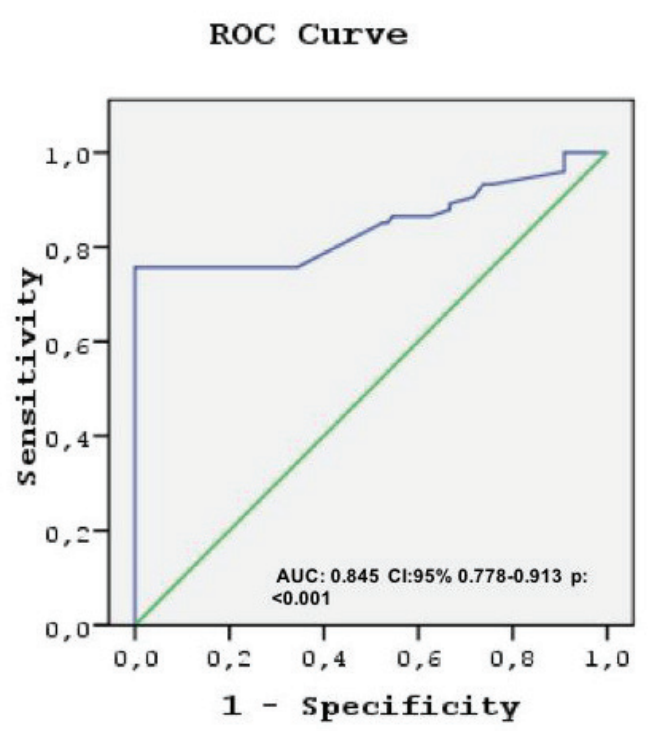

Figure 1. Receiver operating characteristic curves of the $\mathrm{Qp} / \mathrm{Qs}$ ratio for predicting mortality

Op/Qs: pulmonary to systemic blood flow ratio, ROC: Receiver operating characteristics, $\mathrm{Cl}$ : Confidence interval, AUC: Area under curve

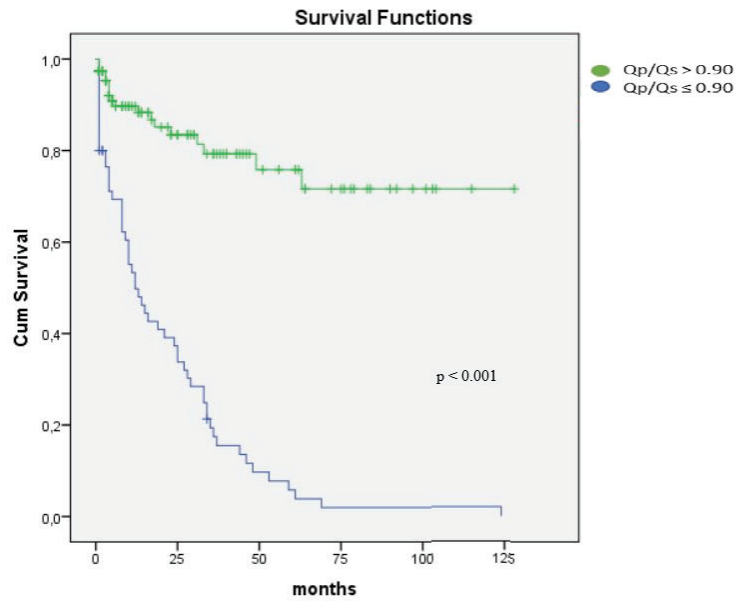

Figure 2. Kaplan-Meier survival estimates for mortality in all patients with precapillary pulmonary hypertension based on the $\mathrm{Qp} / \mathrm{Qs}$ ratio of $\leq 0.90$ vs. $>0.90$

Op/Qs: pulmonary to systemic blood flow ratio

with $\mathrm{PH}$, except in settings with technical obstacles in our clinic. In real-life practice, without any shunting, the Qp/Qs ratio should be equal to 1 . However, during routine RSCC 
procedures in patients with high-risk status and precapillary $\mathrm{PH}$, the $\mathrm{Qp} / \mathrm{Qs}$ ratio calculated using the Fick method was $<1$. $\mathrm{SpaO}_{2}$ was lower than $\mathrm{SmvO}_{2}$ calculated using the formula; therefore, the $\mathrm{Qp} / \mathrm{Qs}$ ratio was calculated as $<1$. In the absence of shunting, the downward deviation of the Qp/Os value from the expected normal value of 1 might initially appear to be strange in a closed-loop system and might be ignored as test result variability. However, the Qp/Os ratio calculated using the Fick method is based on oxygen consumption, and the main determinant of this ratio is a difference between $\mathrm{SpaO}_{2}$ and $\mathrm{SmvO}_{2}$. Moreover, $\mathrm{SmvO}_{2}$ is measured directly from the pulmonary artery (12) or calculated using a formula (11). However, various potential flow sources such as the coronary sinus (CS) can be neglected by calculating $\mathrm{SmvO}_{2}$ from $\mathrm{SsvcO}_{2}$ and $\mathrm{SivCO}_{2}$. This may not matter in patients with normal cardiac function. However, this phenomenon becomes important in patients with heart failure (13). CS oxygen saturation $\left(\mathrm{ScsO}_{2}\right)$ was a strong predictor of the severity of heart failure due to deranged metabolic demands (14). Similarly, we thought that in the presence of right ventricular dysfunction caused by a chronic pressure overload in $\mathrm{PH}$, the metabolic demand of the right ventricle increases, and it may result in reduced $\mathrm{ScsO}_{2}$. This causes a difference between $\mathrm{SpaO}_{2}$ and $\mathrm{SmvO}_{2}$ calculated using the formula. A study that supported our hypothesis showed that the major reason for the calculation between average venous oxygen saturation and $\mathrm{SpaO}_{2}$ was the deoxygenated blood of the CS in patients who underwent cardiac surgery (15). While the contribution of deoxygenated blood derived from the myocardium via the $\mathrm{CS}$ to venous $\mathrm{SO}_{2}$ can be taken into account in the measurement of $\mathrm{SmvO}_{2}$ from the pulmonary artery, the effect of the myocardium can be ignored in the measurement of $\mathrm{SO}_{2}$ from the central veins. Therefore, direct measurement of $\mathrm{SmvO}_{2}$ through pulmonary artery catheterization is more accurate in patients with critical illness (16), including patients undergoing cardiac surgery and/or patients with impaired cardiac function $(17,18)$. The contribution of $\mathrm{CS}$ drainage to venous $\mathrm{SO}_{2}$ could have significant effects in the late stages of $\mathrm{PH}$ that might also serve as a basis for the $\mathrm{Qp} / \mathrm{Qs}$ deviation in the Fick method (19). In the present study, we think that the $\mathrm{SpaO}_{2}$ value is lower than that of $\mathrm{SmvO}_{2}$ because of right ventricular dysfunction in patients with precapillary $\mathrm{PH}$. The low $\mathrm{SpaO}_{2}$ indicates that the heart cannot meet the tissue oxygen demand. The Qp/Qs ratio was calculated as $<1$ because a low $\mathrm{SpaO}_{2}$ and, not surprisingly, decreased $\mathrm{Qp} / \mathrm{Qs}$ ratio was an independent predictor of mortality. Similarly, $\mathrm{SpaO}_{2}$ was shown to be a more valuable prognostic factor than the cardiac index in patients with PH (20).

\section{Study Limitations}

This retrospective cohort analysis had several limitations. First, our study was conducted on a limited number of patients from a single center without any data about treatment-related issues, which can potentially influence outcomes. Second, blood samples from the CS were not obtained. Analyses of $\mathrm{ScsO}_{2}$ that can reflect an intrinsic error in the calculation of $\mathrm{SmvO}_{2}$ should be ideally incorporated in the final evaluation of patients with $\mathrm{PH}$ and right ventricular dysfunction. However, the potential value of this issue in calculating the $\mathrm{Qp} / \mathrm{Qs}$ ratio through the Fick method remains to be established. Third, we could not compare $\mathrm{SmvO}_{2}$ with $\mathrm{SpaO}_{2}$ because of the absence of oxygen saturation values in our hospital records. Fourth, thermodilution, which is the preferred method for determining cardiac output in patients with $\mathrm{PH}$ (19), was not utilized in this cohort because it was not available during the study period. Therefore, we could not compare the cardiac output obtained by thermodilution with $\mathrm{Op}$ and Qs calculated using the Fick method. Essentially, further prospective randomized controlled studies with larger sample sizes are strongly recommended for the validation of the results of this study.

\section{CONCLUSION}

In this study, decreased $Q p / Q$ s ratio calculated using the Fick method was an independent predictor of mortality in patients with precapillary PH without left-to-right shunts. This prognostic implication was based on the difference between $\mathrm{SpaO}_{2}$ and $\mathrm{SmvO}_{2}$ calculated using the formula. Nevertheless, it remains to be elucidated whether this is a reflection of an intrinsic methodological flaw in the Fick method.

\section{ETHICS}

Ethics Committee Approval: This retrospective cohort study was conducted in the Department of Cardiology of Dokuz Eylül University Hospital. This study was approved by the Local Ethics Committee (no: 2018/07-32, date: 15.03.2018).

Informed Consent: Informed consent was obtained for the RSCC procedure from all patients.

\section{Authorship Contributions}

Surgical and Medical Practices: B.Ş., Concept: B.Ş., B.A., E.Ö., Design: B.S., B.A., M.B.Y., M.B., C.S., Data Collection or Processing: B.Ş., B.A., E.Ö., D.S., B.Ö.K., K.C.T., Analysis or Interpretation: B.Ş., B.A., M.B.Y., E.Ö., D.S., B.Ö.K., B.Ac., M.B., C.S., Literature Search: B.Ş., Writing: B.Ş., B.A., M.B.Y., E.Ö., D.S., B.Ö.K., B.Ac., K.C.T., M.B., C.S. 
Conflict of Interest: No conflict of interest was declared by the authors.

Financial Disclosure: The authors declared that this study received no financial support.

\section{REFERENCES}

1. Galiè N, Humbert M, Vachiery JL, Gibbs S, Lang I, Torbicki A, et al. 2015 ESC/ERS Guidelines for the diagnosis and treatment of pulmonary hypertension: The Joint Task Force for the Diagnosis and Treatment of Pulmonary Hypertension of the European Society of Cardiology (ESC) and the European Respiratory Society (ERS): Endorsed by: Association for European Paediatric and Congenital Cardiology (AEPC), International Society for Heart and Lung Transplantation (ISHLT). Eur Heart J 2016;37:67-119.

2. Stępnowska E, Lewicka E, Dąbrowska-Kugacka A, Miękus P, Raczak G. Prognostic factors in pulmonary arterial hypertension: Literature review. Adv Clin Exp Med 2017;26:549-53.

3. Benza RL, Miller DP, Barst RJ, Badesch DB, Frost AE, McGoon $\mathrm{MD}$. An evaluation of long-term survival from time of diagnosis in pulmonary arterial hypertension from the REVEAL Registry. Chest 2012;142:448-56.

4. Wang LY, Lee KT, Lin CP, Hsu LA, Wang CL, Hsu TS, et al. LongTerm Survival of Patients with Pulmonary Arterial Hypertension at a Single Center in Taiwan. Acta Cardiol Sin 2017;33:498-509.

5. Weatherald J, Boucly A, Sitbon O. Risk stratification in pulmonary arterial hypertension. Curr Opin Pulm Med 2018;24:407-15.

6. Kylhammar D, Kjellström B, Hjalmarsson C, Jansson K, Nisell M, Söderberg $S$, et al. A comprehensive risk stratification at early follow-up determines prognosis in pulmonary arterial hypertension. Eur Heart J 2018;39:4175-81.

7. Uznańska-Loch B, Wikło K, Trzos E, Wierzbowska-Drabik K, Chrzanowski $\nvdash$, Kasprzak JD, et al. Advanced and traditional electrocardiographic risk factors in pulmonary arterial hypertension: the significance of ventricular late potentials. Kardiol Pol 2018;76:586-93.

8. Zeidifard E, Silverman M, Godfrey S. Reproducibility of indirect (CO 2 ) Fick method for calculation of cardiac output. J Appl Physiol 1972;33:141-3.

9. Debl K, Djavidani B, Buchner S, Heinicke N, Poschenrieder F, Feuerbach $S$, et al. Quantification of left-to-right shunting in adult congenital heart disease: phase-contrast cine MRI compared with invasive oximetry. Br J Radiol 2009;82:386-91.
10. Barst RJ, McGoon M, Torbicki A, Sitbon O, Krowka MJ, Olschewski $\mathrm{H}$, et al. Diagnosis and differential assessment of pulmonary arterial hypertension. J Am Coll Cardiol 2004;43(12 Suppl S):40S-7S.

11. Weber H, Grimm T, Albert J. Die Sauerstoffsättigung des Blutes in den Hohlvenen, im rechten Herzen und in der Pulmonalarterie und Vergleich der Formeln zur Bestimmung des gemischt venösen Blutes bei gesunden Säuglingen und Kindern [The oxygen saturation of blood in the venae cavae, right-heart chambers, and pulmonary artery, comparison of formulae to estimate mixed venous blood in healthy infants and children (author's transl)]. Z Kardiol 1980;69:504-7.

12. Kandel G, Aberman A. Mixed venous oxygen saturation. Its role in the assessment of the critically ill patient. Arch Intern Med 1983;143:1400-2.

13. Zhang J, Shan C, Zhang YU, Zhou X, Li J, Li Y, et al. Blood gas analysis of the coronary sinus in patients with heart failure. Biomed Rep 2015;3:379-82.

14. White M, Rouleau JL, Ruddy TD, De Marco T, Moher D, Chatterjee K. Decreased coronary sinus oxygen content: a predictor of adverse prognosis in patients with severe congestive heart failure. J Am Coll Cardiol 1991;18:1631-7.

15. Bouchacourt JP, Kohn E, Riva J, Hurtado FJ. Contribution of the coronary sinus blood to the pulmonary artery oxygen saturation gradient in cardiac surgery patients. Minerva Anestesiol 2011;77:579-84.

16. Gutierrez G. Central and Mixed Venous O2 Saturation. Turk J Anaesthesiol Reanim 2020;48:2-10.

17. Lorentzen AG, Lindskov C, Sloth E, Jakobsen CJ. Central venous oxygen saturation cannot replace mixed venous saturation in patients undergoing cardiac surgery. J Cardiothorac Vasc Anesth 2008;22:853-7.

18. Scheinman MM, Brown MA, Rapaport E. Critical assessment of use of central venous oxygen saturation as a mirror of mixed venous oxygen in severely ill cardiac patients. Circulation 1969;40:165-72.

19. Hoeper MM, Maier R, Tongers J, Niedermeyer J, Hohlfeld JM, Hamm $M$, et al. Determination of cardiac output by the Fick method, thermodilution, and acetylene rebreathing in pulmonary hypertension. Am J Respir Crit Care Med 1999;160:535-41.

20. Khirfan G, Almoushref A, Naal T, Abuhalimeh B, Dweik RA, Heresi GA, et al. Mixed Venous Oxygen Saturation Is a Better Prognosticator Than Cardiac Index in Pulmonary Arterial Hypertension. Chest 2020;158:2546-55. 